Lucrările Seminarului Geografic Dimitrie Cantemir

Vol. 45, October 2017, pp. 109-124

http://dx.doi.org/10.15551//sgdc.v45i0.09

\title{
The Racova catchment. Geomorphological peculiarities
}

\section{Claudia Samoilă ${ }^{1}$, Ion Ioniță ${ }^{1}$}

${ }^{1}$ Alexandru Ioan Cuza University of Iasi, Romania.

To cite this article: Samoilă, C. \& Ioniță, I. (2017). The Racova catchment. Geomorphological peculiarities. Lucrările Seminarului Geografic Dimitrie Cantemir, Vol. 45, pp. 109-124. DOI: 10.15551/lsgdc.v45i0.09

To link to this article: http://dx.doi.org/10.15551/lsgdc.v45i0.09 


\title{
THE RACOVA CATCHMENT. GEOMORPHOLOGICAL PECULIARITIES
}

\author{
Claudia Samoilă ${ }^{1}$, Ion Ioniţă ${ }^{1}$
}

\begin{abstract}
The Racova Catchment, located within the southern border of the Central Moldavian Plateau is stretching on 32,908 ha. From the range of sedimentary layers, specific to the Moldavian Plateau, the erosion outcrop Middle and Late Miocene (Sarmatian/Serravillian and Maeotian/Tortonian) formations plus the recent Quaternary ones. The sandy-clayey - clayey-sandy Kersonian (Upper Sarmatian) and clayey-sandy - sandy Maeotian strata lie in a general homocline (monocline) structure. The subsequent valley of Racova, through its almost cross orientation against the general S-SE tilt of the geological formations, clearly emphasizes the first order structural asymmetry. This lay down in the local topography by the large double and north-facing cuesta front of Racova developed on the right side of the catchment. At its turn, the left slope of the Racova Valley is pretty heavily dissected by tributaries which sculptured reconsequent or askew subsequent valleys. That's why it is far away different from the classical shape of a gentle south-looking cuesta back slope. The reconsequent valleys, north-south oriented and some more developed, obsequent valleys, south-north oriented, from Racova cuesta front highlight the second-order morpho-structural asymmetry. That is marked by the presence of lower amplitude cuestas with their west-facing front and the east-looking back slope. The local landforms are typically hilly within this framework of noticeable cuesta extension and small structurallithological platforms with peripheral position. The prevailing genetic relief type is represented by the sculptural (fluvio-denudational), followed from great distance by the fluvial accumulation and structural-lithologic relief. Besides the large extension of cuestas, the main peculiarities of the study area refer to the following: severe land fragmentation/dissection and almost the even distribution of slopes on both sides of the Racova Catchment, and noticeable prevailing of the valley sides $(78.3 \%$ of catchment area). On the whole, the cuesta fronts amounts $62 \%$ of the slopes area, and two-thirds of the cuesta back slopes are heavily degraded. The structural-lithological plateaus have a reduced and peripheral incidence and the fluvial terraces are preserved on small patches. Based on field data, three compartments with distinct features have been separated.
\end{abstract}

Keywords: sculptural relief, structural asymmetry, subsequent valley, double cuesta front

\section{Introduction}

Racova catchment is located in the southern part of the Central Moldavian Plateau, which is regarded as the most typical hilly subunit across Moldavian Plateau of eastern Romania. In course of time, it succeeded to draw many specialists' attention and concerns. A century ago, David M. (1918, 1920, 1941) called this area the "Sarmatic Plateau of Moldavia", where the true plateau character is given by the cuestas (coasts in Romania for the cuesta

1 “Al. I. Cuza" University of Iasi, Faculty of Geography and Geology, Department of Geography, Bd.Carol I 20A, 700505, Iasi, Romania, samoilaclaudia@yahoo.com 
fronts) and by the structural platforms. He also supported the tectonic origin of the Moldavian Plateau by invoking some accidents, flexures or tectonic lines, relying on the erroneous dating of geological formations.

Văscăuţeanu Th. (1928) established the Bessarabian age (Middle Sarmatian) of the claymarl strata around the city of Iaşi. Jeanrenaud P. $(1953,1961,1966,1971)$ found a continuity in sedimentation process between Sarmatian and Maeotian, and the "fault breccias" signaled by David M. (1941) are, in fact, the result of landslides. Subsequently, Martiniuc C. (1955), Sârcu I. (1956), Băcăuanu V. (1968) and Băcăuanu et al. (1980) imposed the hypothesis of the sculptural origin of the Moldavian Plateau, based on "rock and base level differences".

Ploscaru D. (1973) was concerned with overall questionable results by the geomorphological study of the Central Moldavian Plateau. The synthesis work elaborated by Băcăuanu V. et al. (1980) represents a reference paper from the physical and human geographic approach of the Moldavian Plateau. Then, other physical-geographic studies of the Central Moldavian Plateau focus on its western part (Budui V., 2009) and central part (Patriche V., 2003).

Ioniţă I (1985, 1998 and 2000) brings new contributions to proper understanding of the cuestas relief in the Moldavian Plateau by taking into account a double stratigraphic dipping system, which generates two types of morpho-structural asymmetries. In this spirit, several geomorphological studies were performed on some catchments located in the Central Moldavian Plateau, such as those elaborated by Topşa G. (2011), Darie Petronela (2013), Puflea Suzana (2014), Bojoagă I. (2015), Curea D (2015) and Andrei A. (2016). The present paper enters into this last mentioned research trend in order to highlight the geomorphological particularities of the Racova Catchment.

\section{Materials and methods}

To complete the scientific approach taken, the stages of a geomorphological study were followed in a synchronous or progressive way, namely: documentation, field and office work. Such an approach, based on collecting, processing and interpretation of field and laboratory data, contributed to obtain a valuable database.

The cartographic and digital sources consisted in using of the following materials: topographical maps at the 1:5,000 and 1:25,000 scales, the 2009 aerial orthophotos, 2012 LiDAR images, made available by the Prut-Bârlad Catchment Administration, and the geological map of central Moldova between Siret and Prut drawn up by Jeanrenaud P. (1966 and 1971).

Among the activities of the field work are the visual observations, specific measurements, geomorphological mapping, digging soil profiles and soil sampling. Particular attention was given to field validation of the results obtained in the office, respectively the field verification of cartographic information.

Regarding the work methodology were taken into account both traditional methods, such as topographic levelling using Trimble Total Station or GPS, augering with Eijkelkamp kit for estimating the sediments thickness along the gully bottom and the modern methods, namely use of GIS techniques.

Thus, the main attention was focused on the following activities:

- $\quad$ Drawing the geomorphologic map at the 1:5,000 scale; 
- Making thematic maps such as those regarding the hypsometry, slope gradient, map of total erosion and distribution of gullies and landslides;

- Statistical and mathematical processing of field and laboratory data using Excel 2010.

\section{The study area}

The Racova Catchment is located in the southern border of the Central Moldavian Plateau at the contact with Tutova Rolling Hills. With a length of $49 \mathrm{~km}$ between La Neamt Hill $(403 \mathrm{~m})$ and the junction with Bârlad River on WNW-ESE direction, the catchment occupies 32,908 ha. In the north, it is confined by the Buda/Stemnic catchment, eastwards by the Bârlad valley, and south and south-westwards by the Lipova, Tutova, Simila, Studinet catchments.

From a geological point of view, the Racova Catchment is sculptured in Middle and Late Miocene (Sarmatian/Serravillian and Maeotian/Tortonian) layers. It developed above the Bessarabian (Middle Sarmatian) calcareous-sandstone plaque, in clayey-sandy and sandyclayey formations, almost exclusively deposited in deltaic facies as cross-bedded strata (Jeanrenaud P., 1961, 1965, 1971). These formations are mostly Kersonian in age (Upper Sarmatian), entirely developed on vertical, and secondary Maeotian in age, as erosion remnants on cineritic sandstones or sands in the highest hilltops. The thickness of the Kersonian deltaic layers at Pungeşti, from the upper Racova, is about $250 \mathrm{~m}$ as estimated by Jeanrenaud (1971). Besides these older layers, there are also recent Quaternary formations, such as: eluvia, diluvia, colluvia, proluvia, and alluvia. The Kersonian and Maeotian sedimentary layers are lying in a general homocline (monocline) structure, showing a gentle dipping of 7-8 m/km on the N-NW - S-SE direction (Jeanrenaud P., 1961, 1965, 1971; Ionesi L., 1989, 1994). Both terms, monocline and homocline, have been used to describe "beds dipping in one direction". However, homocline is a sedimentary rock unit where the underlying strata are tilted in the same direction, especially with near uniform dip angle.

The continental temperate climate has excessive nuances and is characterized by an annual average temperature of about $9.9^{\circ} \mathrm{C}$ at Vaslui and $9.7^{\circ} \mathrm{C}$ at Plopana (data from A.N.M.CEEX 756-2006). The mean annual precipitation for the period 1963-2015 is $530.6 \mathrm{~mm}$ at Puşcaşi, situated in the Racova valley-bottom at $105 \mathrm{~m}$ a.s.l., and $583.7 \mathrm{~mm}$ at Floreşti, located at $255 \mathrm{~m}$ a.s.l. in the upper catchment of Simila. In this context, it is estimated that the average annual precipitation is about $700 \mathrm{~mm} \mathrm{yr}^{-1}$ in the higher area exceeding $400 \mathrm{~m}$ altitude.

The natural vegetation consists of forest-steppe in the lower area and mostly broadleaf forest including durmast (Quercus petraea) and its mixture with the common beech (Fagus silvatica) or only beech on the highest hilltops.

In these natural conditions, it was found an altitudinal zoning of soils, namely: the Cambic Chernozems in the lower area under forest steppe and predominance of forest soils comprising Phaeozioms, Preluvosoils and Luvosoils. From the azonal soils are found Aluviosoils, Regosoils and Anthrosoils types. 


\section{Results and Discussions}

4.1. The overall morphography and morphometry of Racova catchment are typical to hilly landforms of Central Moldavian Plateau. Useful information on these issues are based on achieving the Digital Elevation Model (DEM), obtained through the vectorization of the topographic maps in 1:5,000 scale by means of T.N.T. Mips v.6.9. Programme.

The southern border of the catchment is dominated by the famous double cuesta of Racova, characterized by high relief amplitude, up to $340 \mathrm{~m}$, and high intensity of the present geomorphologic processes.

The local relief is a typically hilly one with the average height of $241 \mathrm{~m}$. Extreme altitudes are $485.5 \mathrm{~m}$ a.s.l. on the southern hilltop of catchment, in Mângălăria Hill and $89 \mathrm{~m}$ a.s.l. in the Bârlad floodplain (Figure no. 1). This is closely linked to the formation and development of the subsequent valley, sometimes slightly diagonal (oblique) to Racova in the general homocline (monocline) structure of Moldavian Plateau.

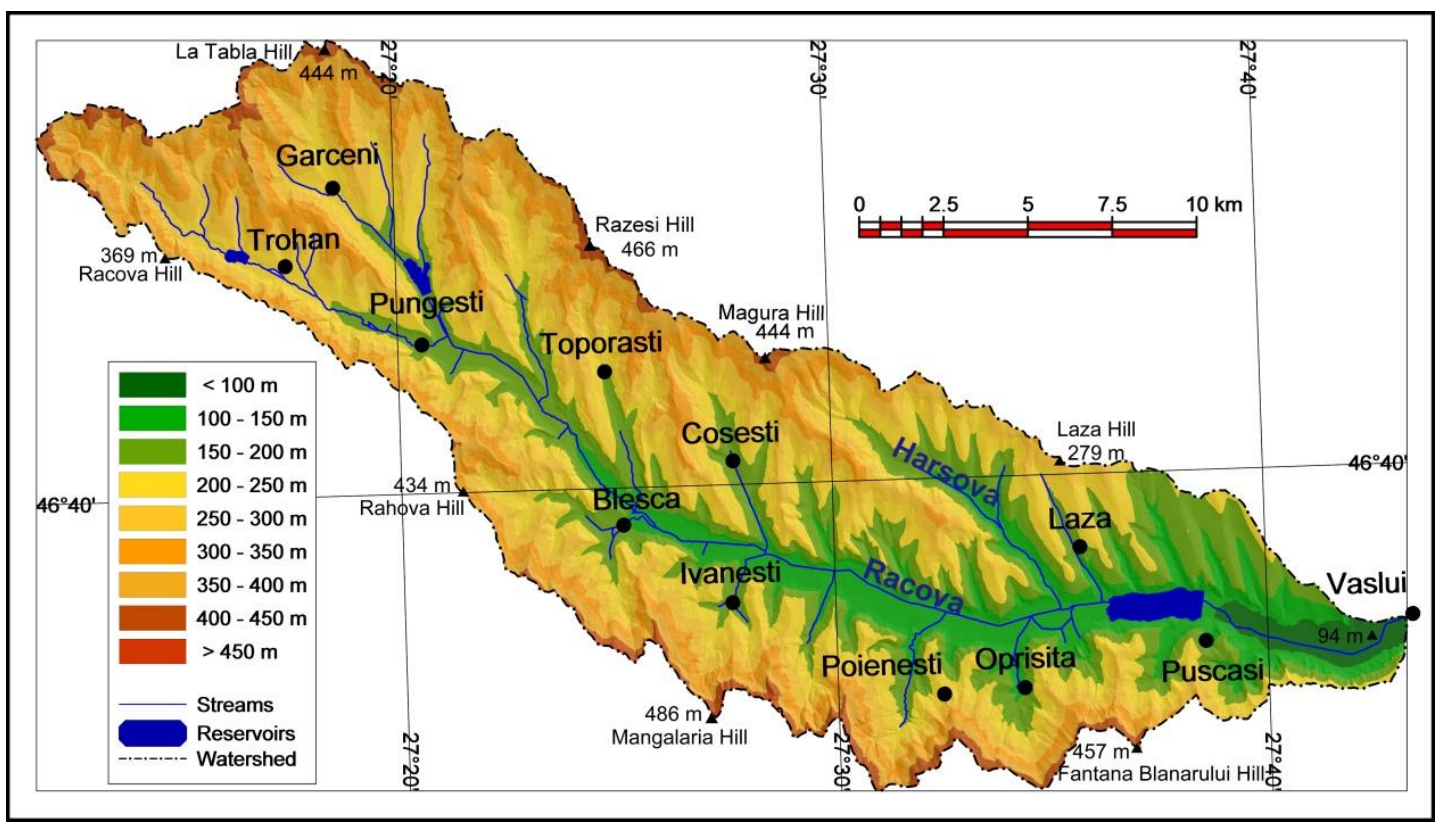

Fig. 1. Hypsometric map of the Racova Catchment

Almost 44.4\% (14,600 ha) from the study area has the altitude between $200-300 \mathrm{~m}$, which underlines the local hilly topography (Figure no. 2). Based on the information from Figure no. 3, it was estimated that the mean slope was $18.7 \%$, differentiated as follows: $17.8 \%$ on the left side of the Racova Catchment and $20.6 \%$ on the right side. Obviously, we would have expected that the average slope would be much more reduced on the left side because, as a whole, it represents a southern looking cuesta back slope. So, this particularity, almost the same value and distribution of the geo-declivity on both sides of the Racova catchment is determined especially by the strong land dissection, combined with geological and climatic conditions. 


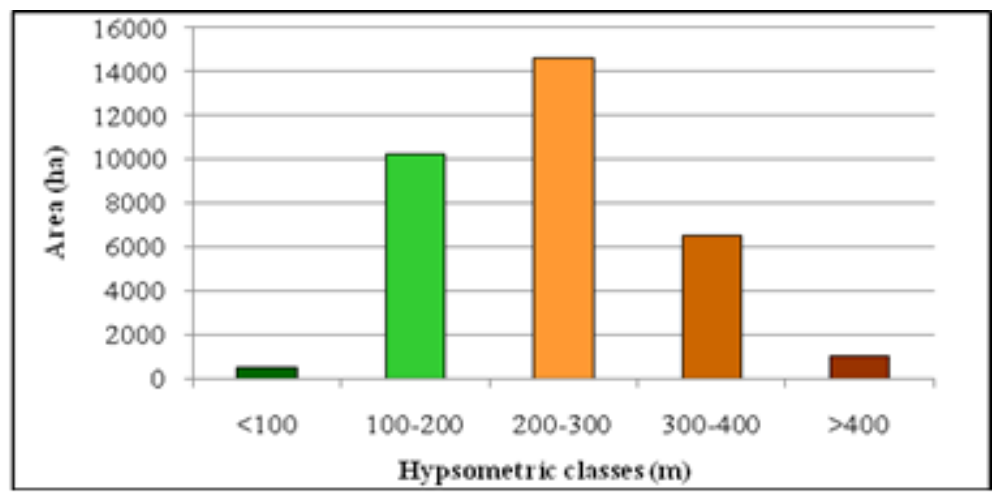

Fig. 2. Histogram of the hypsometric classes in the Racova Catchment

The highest slopes values $\geq 27 \%$ are found in the cuesta fronts, in a series of heavily degraded cuesta back slopes, and in the upper catchment of most of the Racova tributaries. Among these areas the upper step of the Racova cuesta front comes off, very well shaped between Bleşca and Poieneşti, where it overlie on Maeotian cineritic sandstones, sands and clayey-sands.

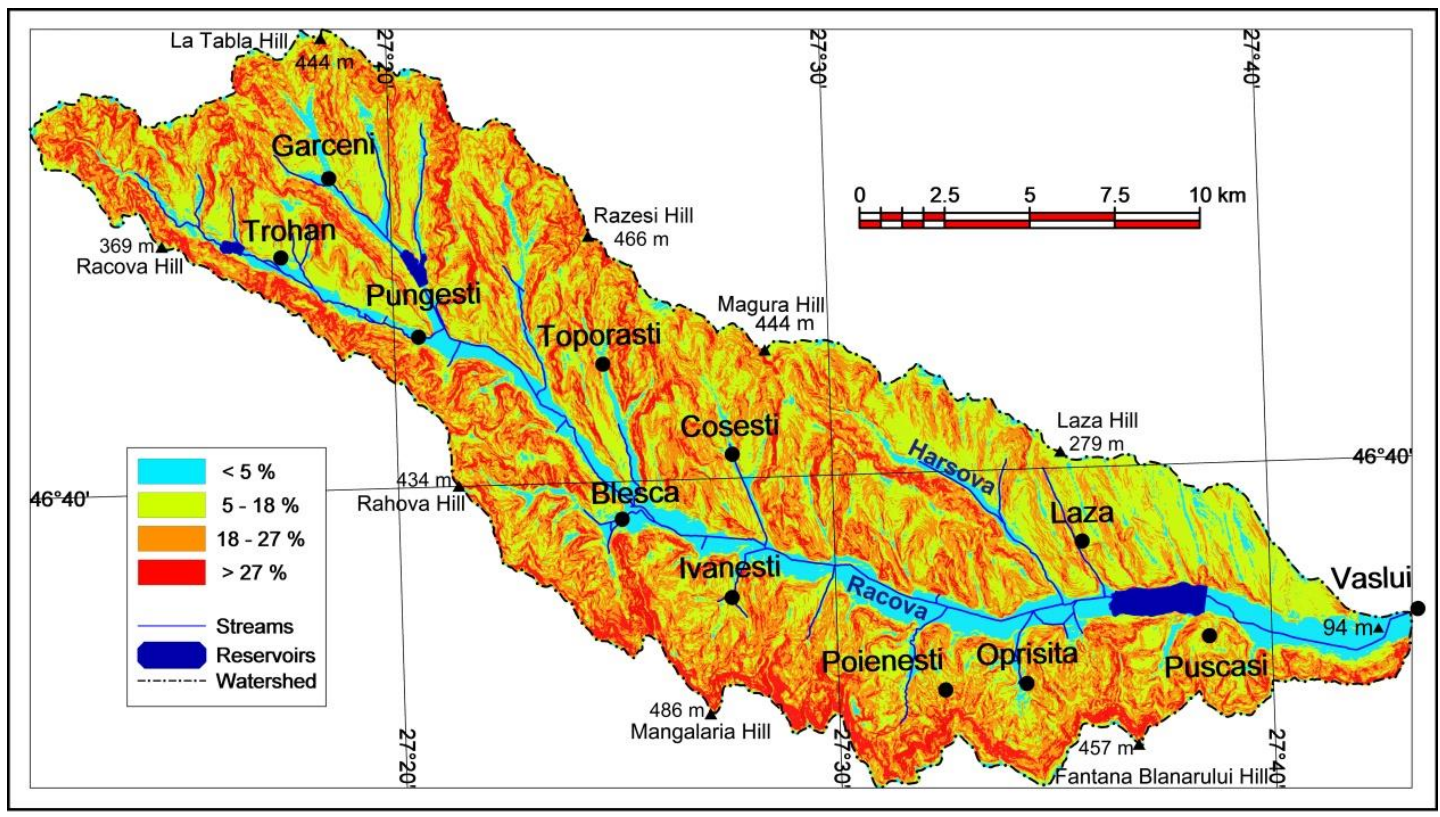

Fig. 3. Slope map in the Racova Catchment

According to the histogram of slopes, most of the land, respectively $87 \%$ of the studied area has slopes $\geq 5 \%$ which shows that the Racova Catchment displays a high erosion potential. From the declivity point of view, $46.4 \%$ (15,269 ha) of this catchment is not suitable to be used as arable land, since their slope exceeds $18 \%$. The land with slope between $5-18 \%$ is stretching on 13,252 ha ( $40.3 \%$ of the total) and comprises cuesta black-slopes and the lower third of cuesta front (Figure no. 4). 


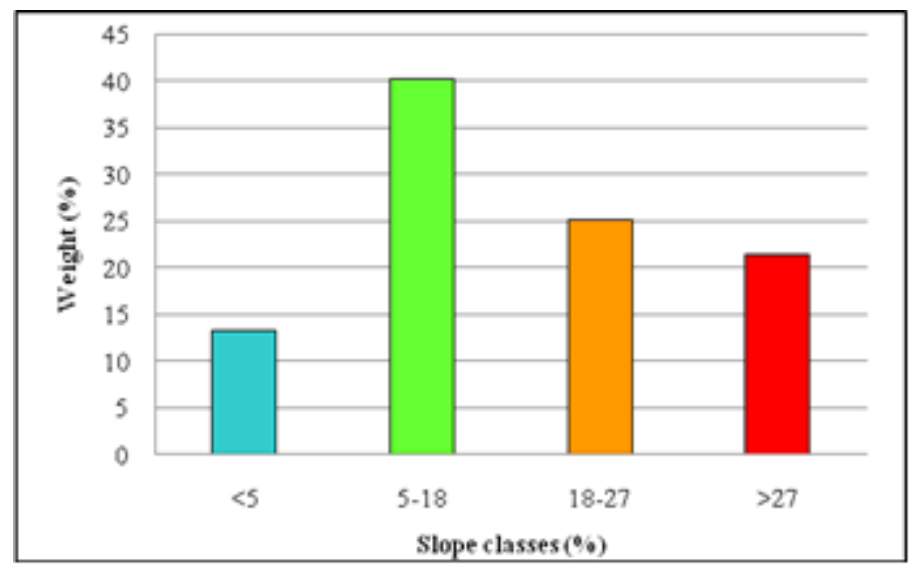

Fig. 4. Distribution of the slope classes within the Racova Catchment

4.2. The main genetic relief types in the study area are the ones specific to the Central Moldavian Plateau, namely: the structural-lithologic relief, the sculptural (fluviodenudational) relief in generally homocline structure and the fluvial accumulation relief (Figure no. 5).

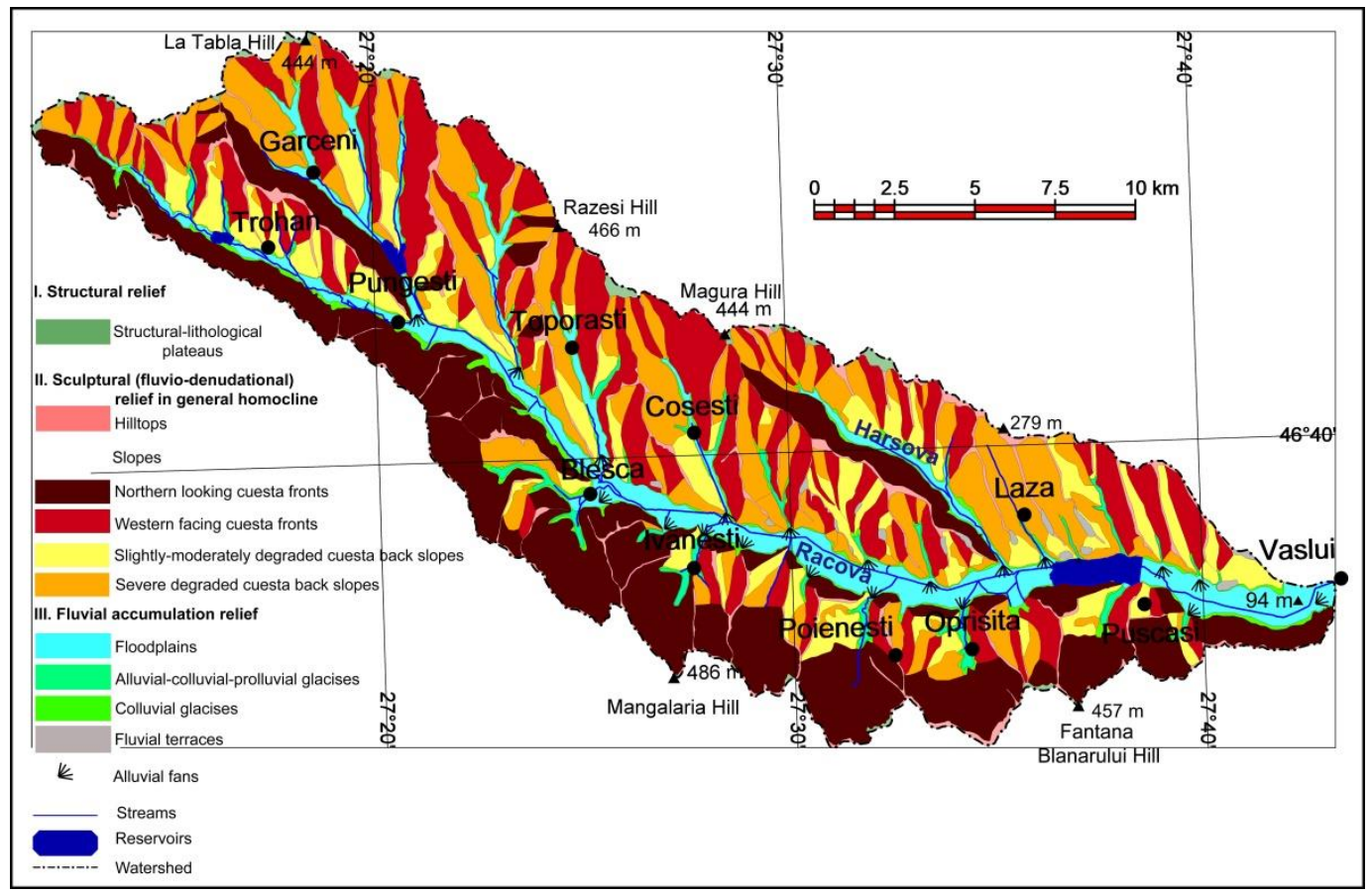

Fig. 5. Geomorphological map of the Racova Catchment

The sculptural (fluvio-denudational) topography represents the prevailing genetic type as distribution, since it covers 27,353 ha, representing $83.1 \%$ of the total catchment area. It is 
followed by accumulation landforms with $16.1 \%$ (5,309 ha) and the structural-lithological ones with $0.8 \%$ (Table no 1 ).

Table 1. Main genetic relief types and landforms in the Racova Catchment

\begin{tabular}{|c|c|c|c|c|}
\hline \multirow[t]{2}{*}{ No.crt. } & \multirow[t]{2}{*}{ Types of relief } & \multirow[t]{2}{*}{ Landforms } & \multicolumn{2}{|c|}{ Area } \\
\hline & & & (ha) & $(\%)$ \\
\hline \multirow[t]{2}{*}{1} & \multirow[t]{2}{*}{ Structural relief } & Total & 244.54 & 0.74 \\
\hline & & Structural-lithological plateaus & 244.54 & 0.74 \\
\hline \multirow[t]{9}{*}{2} & \multirow{9}{*}{$\begin{array}{l}\text { Sculptural (fluvio- } \\
\text { denudational) relief } \\
\text { in general } \\
\text { homocline } \\
\text { (monocline) } \\
\text { structure }\end{array}$} & Total & $27,353.54$ & 83.12 \\
\hline & & Hilltops & $1,576.15$ & 4.79 \\
\hline & & Slopes, of which: & $25,777.39$ & 78.33 \\
\hline & & Cuesta fronts: & $15,982.55$ & 48.57 \\
\hline & & $\begin{array}{l}\text {-Northern facing (first order } \\
\text { structural asymmetry) }\end{array}$ & $9,325.06$ & 28.34 \\
\hline & & $\begin{array}{l}\text {-Western facing (second order } \\
\text { structural asymmetry) }\end{array}$ & $6,657.49$ & 20.23 \\
\hline & & Cuesta black slopes: & $9,794.84$ & 29.76 \\
\hline & & - slightly-moderately degraded & $3,430.49$ & 10.42 \\
\hline & & - severe degraded & $6,364.35$ & 19.34 \\
\hline \multirow[t]{4}{*}{3} & \multirow{4}{*}{$\begin{array}{l}\text { Fluvial } \\
\text { accumulation relief }\end{array}$} & Total & $5,309.92$ & 16.14 \\
\hline & & Floodplains & $3,871.98$ & 11.77 \\
\hline & & $\begin{array}{l}\text { Alluvial-colluvial-prolluvial } \\
\text { glacises }\end{array}$ & $1,212.92$ & 3.69 \\
\hline & & Fluvial terraces & 225.02 & 0.68 \\
\hline & & & 32,908 & 100 \\
\hline
\end{tabular}

On landforms, the largest areas are occupied by slopes which are extending on 25,777 ha $(78.3 \%$ of the Racova Catchment), followed by floodplains, hilltops and glacises. Instead, structural-lithological plateaus and fluvial terraces have a very small share of $0.74 \%$ and respectively $0.68 \%$.

The classical structural relief as structural-lithological plateaus (platforms), in the meaning given by David M. $(1920,1922)$, does not exhibit a marker weight due to the presence of friable formations, less resistant at erosion. However, in some places on the highest hilltops, small plateaus are looming on the Maeotian cineritic sandstones and rarely on Kersonian sands. So, the structural-lithological plateaus have a peripheral position and are missing inside the study area. By this geomorphological particularity, the Racova Catchment is clearly distinguished from the upper Bârlad Catchment, including that of Crasna, formed and developed in similar geological formations.

The most representative structural-lithological plateaus are found on the southern frame of the catchment, at 440-450 m a.s.l. from the Poieneşti Hill, Oprișița Hill, Lacu Babei Hill 
and Fântâna Blănarului Hill overlying on the Maeotian cineritic sandstones and sands. On the northern frame, we only mention the plateau of Măgura Hill (444 m a.s.l., north of the Coşca village) on Maeotian formations and the Făstâci Hill (390-420 m a.s.1.) on Kersonian layers. In addition, we mention the presence of some full standing hills on the Upper Maeotian sandy layers, as in Măngălăria Hill (486 m a.s.1.), Cheia Hill (482 m a.s.1.) and Răzeși Hill (466 m a.s.l.).

Also of interest is the network of valleys developed in the local homoclinal structure, respectively the consequent/reconsequent valleys (e.g. most of the valleys of the left tributaries of Racova), typical or askew (diagonal) subsequent (Racova, Gârceneanca and Hârsova) or obsequent (the valleys of the right tributaries of Racova).

The sculptural (fluvio-denudational) relief within general monocline structure (homocline) represents the prevailing genetic type as distribution, imposed in the relief by two specific landforms, namely: the sculptural hilltops and slopes. The hilltops have a reduced weight ( $4.8 \%$ of the total sculptural relief), the main ones delimiting the studied area by tributaries of Lipova, Tutova Simila, Studinet, Buda or Bârlad. The valley sides (slopes) give the characteristic note of local topography and frequently they represent cuesta fronts and cuesta black-slopes.

For a better understanding of the cuesta relief and, implicitly, the types and landforms in the Moldavian Plateau, Ioniţă I. $(1985,1998,2000)$ recommended to be taken into account two dipping planes of the outcropping layers which are responsible for the double structural asymmetry:

a) First order structural asymmetry, associated with the main dip to the south, of $6 \mathrm{~m}$ $\mathrm{km}^{-1}$, of the geological formations, which comprises the subsequent, typical or askew (oblique) valleys. These valleys are west-east oriented or vice versa and have the asymmetrical classical cross-section. Here, the anti-dip valley side is a cuesta front facing north or north-east generally, and the dip slope is a south or southwest looking cuesta back slope. For example, we mention the valley of Bârlad upstream the confluence with Rebricea, the valleys of Buhăiești, Buda/Stemnic, Racova, Gârceneanca, Hârsova, Crasna Rivers and the valleys of Fălciu Hill etc. What is specific to most of the subsequent valleys is the broad extension of the cuesta back slopes. They are at least twice as large by comparison to the cuesta fronts, and they usually occupy 70-75\% (even $91 \%$ in the lower Crasna) of the catchment area. This feature is resulting from homoclinal shifting, respectively, by the deepening and lateral migration of the streams, according to dipping of the layers, in the context of the neo-tectonic uplifting (Donisă et al., 2009).

The subsequent valleys between the upper Bârlad and the Racova cuesta fronts have, in their turn, asymmetrical cross-sections. However, the prevailing areal growth appears seemingly surprising on the cuesta front, namely: $75 \%$ in the Buhăieşti valley and $53 \%$ in the Stemnic valley. Only in the Racova Catchment we witness left-side predominance, but insufficient for an initial, largely extended, cuesta back slope. This particularity is explained by the faster rate of homoclinal shifting to the south of the more advanced upper Bârlad Valley, which led to the narrowing of the share of the left slope of the Buhăieşti Valley to $25 \%$ and $47 \%$ in the Stemnic Valley (Figure no.6). The latter, though younger, formed and shifted southward on an appreciable portion of the larger initial cuesta back slope of the Racova Valley, contributing to diminishing of its share at $61 \%$, hence under normal weight of about $75 \%$. 


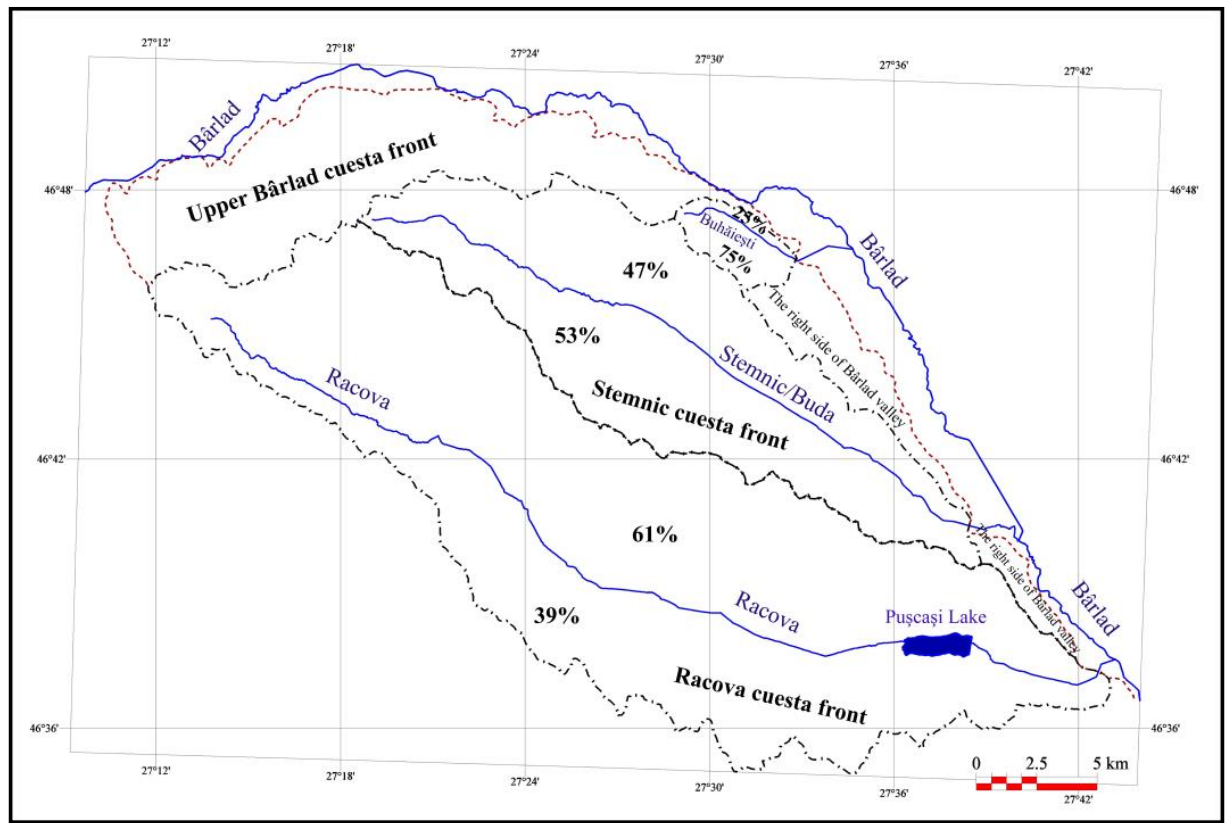

Fig.6. Southward homoclinal shifting of the Racova, Stemnic, Buhăiești and Bârlad rivers

b) The second order structural asymmetry, generated by secondary eastwards dip, of $3 \mathrm{~m} \mathrm{~km}^{-1}$, is dependent upon the neo-tectonic uplifting of the Moldavian Platform at the contact with the Carpathian Orogen. This type of asymmetry is encountered on the most reconsequent valleys, north-south oriented and associated to the left tributaries of Racova, namely: Racoviţa, Toporăşti, Spia, Coşeşti, Oana Valley, Dumbrava, Recea, Dumbrăviţa, Târgului Valley, Hopului Valley, Cristoaia, Hăşculeţ Valley. Usually, their cross-section is asymmetric where the left valley-side is a western looking cuesta front and the right one as eastern facing cuesta back-slope (Figure no.7).

The second order structural asymmetry is also visible in the lower half of the obsequent catchments developed on the Racova cuesta front, downstream of Bleşca, which points out that although short, these valleys are pretty evolved.

Therefore, the appreciable extension of the cuestas is imposed as a basic feature of the local relief. The basic framework is imprinted by the first order structural asymmetry, specific to Racova as main valley and Gârceneanca and Hârsova valleys. The details are shown by the second order structural asymmetry, marked by most valleys of the Racova tributaries. It is worth mentioning that being more extensive, the cuesta fronts amount $62 \%$ of the valley sides area, and two thirds of the cuesta back slopes are severely degraded, which emphasizes the high potential of land degradation in the Racova catchment. 


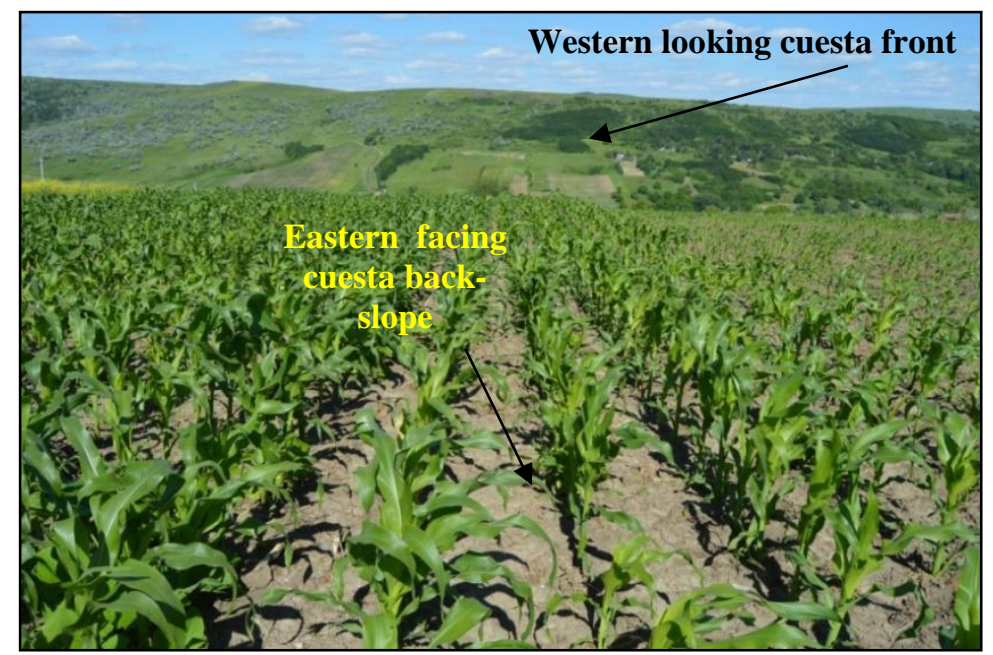

Fig. 7. The second order structural asymmetry in the Toporăşti reconsequent valley (June $8^{\text {th }}$, 2016)

The accumulation relief ranks the second with $16.1 \%$ (5,310 ha) and is represented by fluvial terraces of Racova, floodplains of Racova, Hârsova, Coşeşti, Curseşti, Toporăşti, Gârceneanca, and the alluvial-colluvial-proluvial glacises.

Due to the severe fragmentation of the relief, the gravel scarcity, specific to the Moldovan Central Plateau, and the high intensity of the land degradation, the fluvial terraces have a very limited incidence on 225 ha, respectively $0.68 \%$ of catchment area. Ploscaru D. (1973) identified three valley side terraces with the relative altitude of 20-25 m, 65-70 m and 95-100 $\mathrm{m}$ and a valley bottom terrace of 5-8 $\mathrm{m} \mathrm{r}$.a., which appears sporadically in the Racova Valley. Based on our field observations, we can add a higher terrace of 130-135 m r.a. It should be noted that the lower terraces, with the relative altitude $\leq 60 \mathrm{~m}$, although younger, usually occur at the junction areas, on former alluvial fans.

\subsection{Geomorphologic subdivision}

Under the natural context described above, three distinct compartments can be separated by their geomorphologic features, namely: the western compartment, the central compartment, and the eastern compartment.

The western compartment includes upper Racova Catchment, upstream of Bleşca, with an area of $11,006.7$ ha (33.45\% of the total) and fully developed in Kersonian sandyclayey and clayey-sandy layers.

In this young compartment formed by regressive erosion, the Racova Valley is diagonally (askew) subsequent and firstly highlights the classical model of first order morphostructural asymmetry (Figure no. 8). Thus, the left valley side, S-SW generally facing cuesta back slope, is still wide and amounts $77 \%$ of the compartment area.

In turn, it is dissected by small re-consequent tributaries (Racovița, Hârtog, Spia) that show the more blurred structural asymmetry of the second order. Here, the right slope represents a cuesta back slope looking eastward, and the left one is a western facing cuesta front (Figure no. 9). The only deviation between the valleys of the left Racova tributaries is 
associated to the askew (oblique) subsequent Gârceneanca valley. Its right side is N-NE cuesta front, short, steep, unitary, undifferentiated in two-steps, but slightly dissected by small obsequent dales. Nevertheless, the valleys of its tributaries (Recea and Dumbrava) preserve well the $2^{\text {nd }}$ order structural asymmetry.

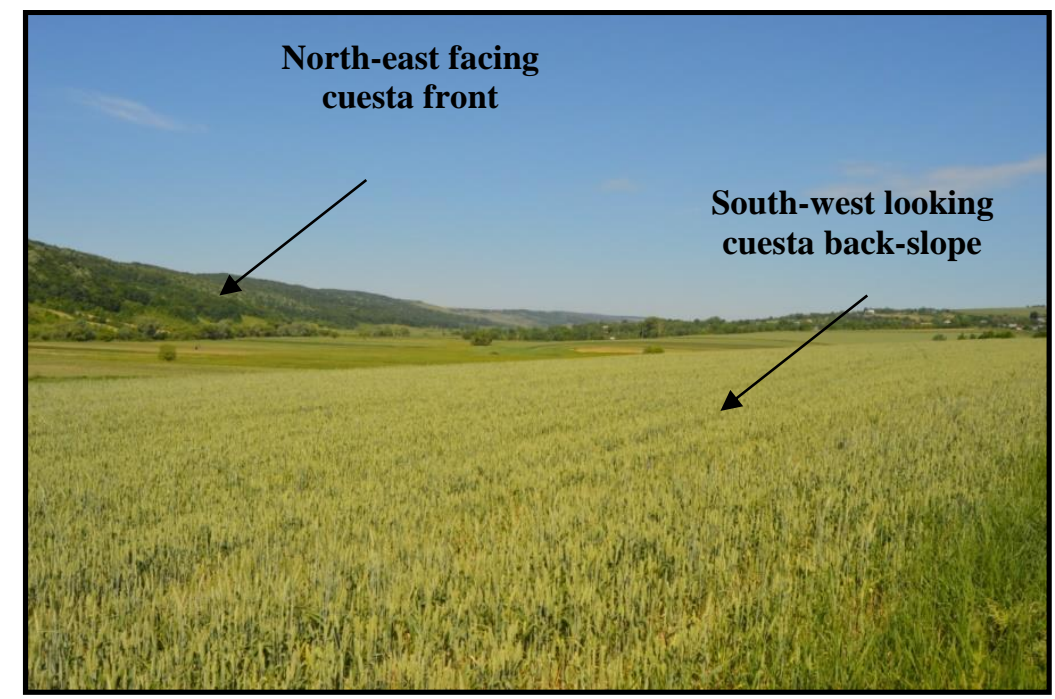

Fig. 8. The first order structural asymmetry on Racova Catchment at Trohan, Vaslui County (June 2 $2^{\text {nd }}, 2015$ ).

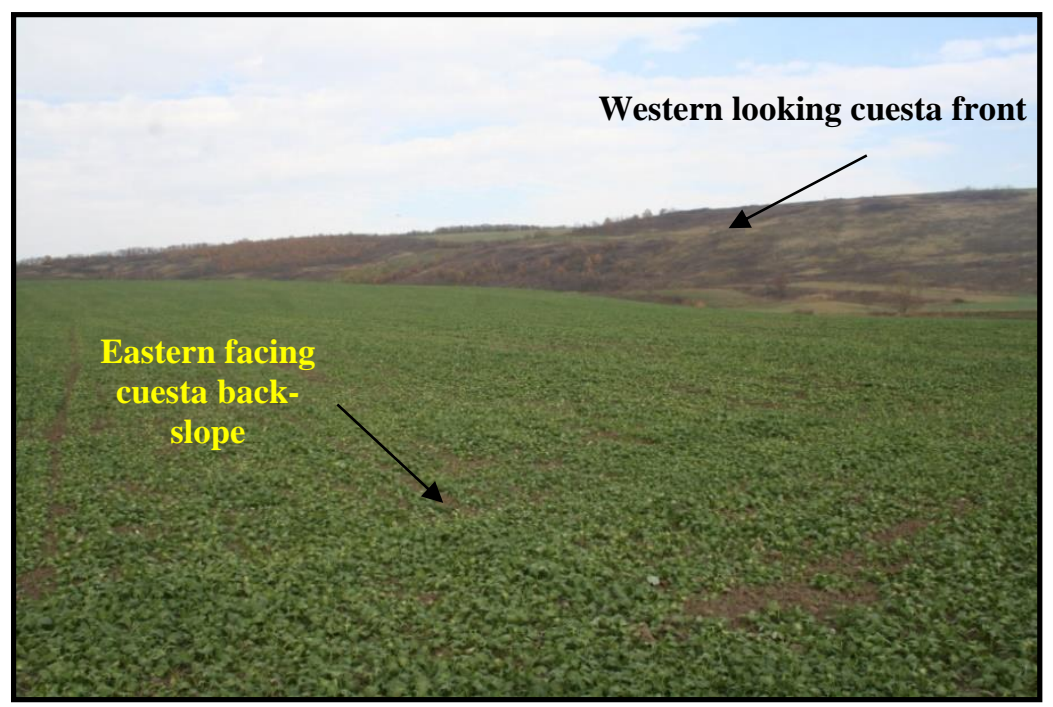

Fig. 9. The second order structural asymmetry in the Hârtog reconsequent valley

(October 21 ${ }^{\text {st }}$, 2013)

The central compartment, between Bleşca and Puşcaşi, includes the middle Racova Catchment and the majority of the lower catchment. This is the largest, most developed and most representative compartment that occupies 19,495 ha (59.2\% of total area) and sculptured in predominantly Kersonian formations and subordinate in Maeotian layers. The latter 
formations occur locally in the form of two erosion remnants on the left hilltop (Răzeși Hill, $466 \mathrm{~m}$ and Măgura Hill, $444 \mathrm{~m}$ ). Conversely, it is well developed in the form of a strip, outlined in the right hilltop or in the upper catchment of the Racova obsequent tributaries (Iezer Hill 460 m, Mangalaria Hill 486 m, Cheia Hill 482 m, Cetatea Hill 479 m, Poienesti Hill 451 m and Fantana Blanarului Hill $457 \mathrm{~m}$ ).

In this compartment, the Racova Valley is typically subsequent, west-east oriented and, therefore, the geomorphologic background is imposed by the first order structural asymmetry. The left side is a southern looking cuesta back slope, strongly dissected by a series of reconsequent tributaries (Toporăști, Valea Oana, Coşeşti, Valea Mare, Dumbrava/Sârbului, Laza, Sauca etc.) and the askew (diagonal) subsequent valley of Hârsova.

The right side, in broad sense, is an ample, north facing double cuesta front, heavily dissected by a series of obsequent tributaries with high erosion power. The double cuesta front of Racova consists of two steps. The lower step, in the form of triangular faces with amplitude of about $100 \mathrm{~m}$, is situated at the base of the right valley side. The second step by higher amplitude (ca. $240 \mathrm{~m}$ ) is well defined in the upper catchment of the obsequent tributaries, at the upper part of the Kersonian formations, but especially on the lower Maeotian strata.

The second step of Racova cuesta front imposes in the local topography through succession of two or three alignments of sliding amphitheatres (hârtoape in Romanian), as in the Ivăneşti catchment (Figure no. 10). Hârjoabă I. (1968) appreciated that the right hilltop migrated far away from Racova river channel due to the regressive evolution of the welldeveloped, obsequent hydrographic network, and the Racova cuesta front appears in the form of a "garland of semicircles welded together".

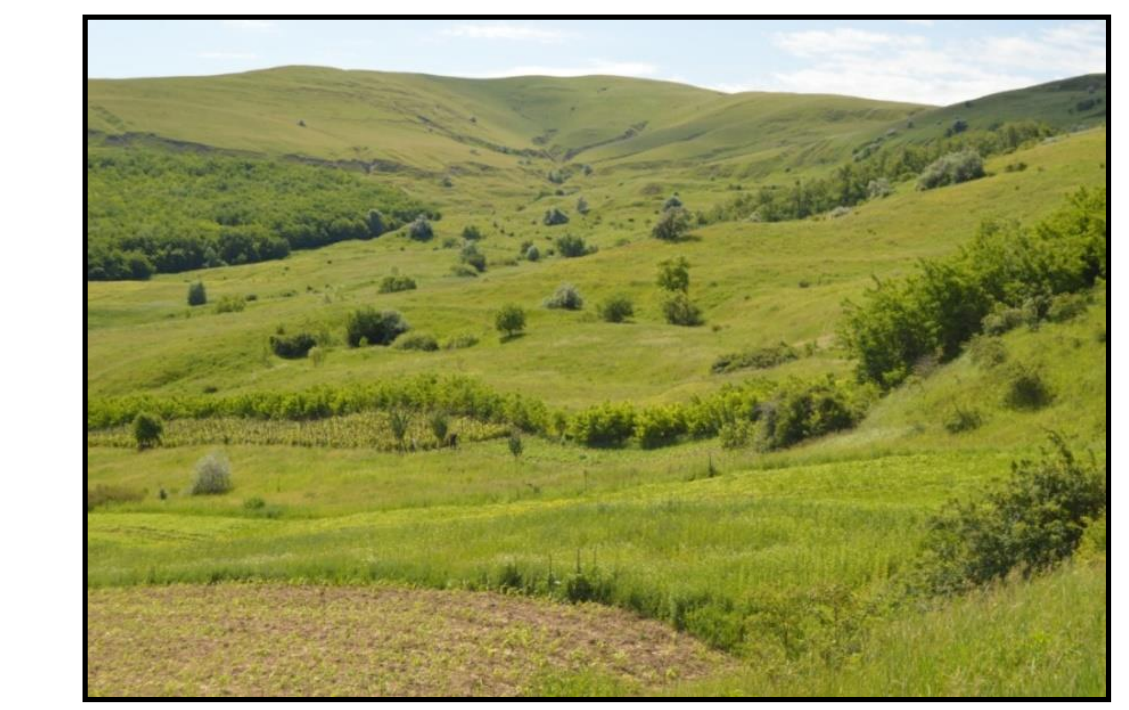

Fig. 10. Second step of the northern looking Raccva cuesta front, south of Ivăneşti (June $7^{\text {th }}$, 2016)

Viewed as a whole, Racova cuesta front has here the amplitude around $340 \mathrm{~m}$, where obsequent catchments were formed each $\leq 1,050$ ha in size, $\leq 5.8 \mathrm{~km}$ long and with high longitudinal slopes. The high tilting of the land here was controlled by the lowered base level of 105-155 $\mathrm{m}$ a.s.l., the predominance of the sandy layers, but especially the noticeable 
consistency of the cineritic sandstones. Those main controlling factors contributed to the supply of solid material in the Racova alluvial channel, and to the relatively slow growth in length of the obsequent valleys. The connection between the two steps of the Racova cuesta front rests on secondary hilltops, buttresses (counterforts) like in shape, between the catchments of the obsequent tributaries.

The initial gentle cuesta back slope was therefore strongly fragmented, vertically and horizontally. At present, it does not at all resemble with the classical model of the subsequent valleys where the cuesta back slope represents a prolonged slope, slightly tilted and slightlymoderately affected by geomorphological processes, especially soil erosion. Moreover, the left valley side (cuesta back slope) of Racova has a steep basal border (scarp), of about 60-70 $m$ amplitude, which often does not represent a terrace front (Figure no. 11). We consider that the formation of this scarp resulted from the evolution of the obsequent tributaries from the Racova cuesta front which, through the abundance of alluvia deposited in the Racova floodplain, contributed to the leftward migration of river channel and, implicitly, to the longterm undermining the base of the left valley side.

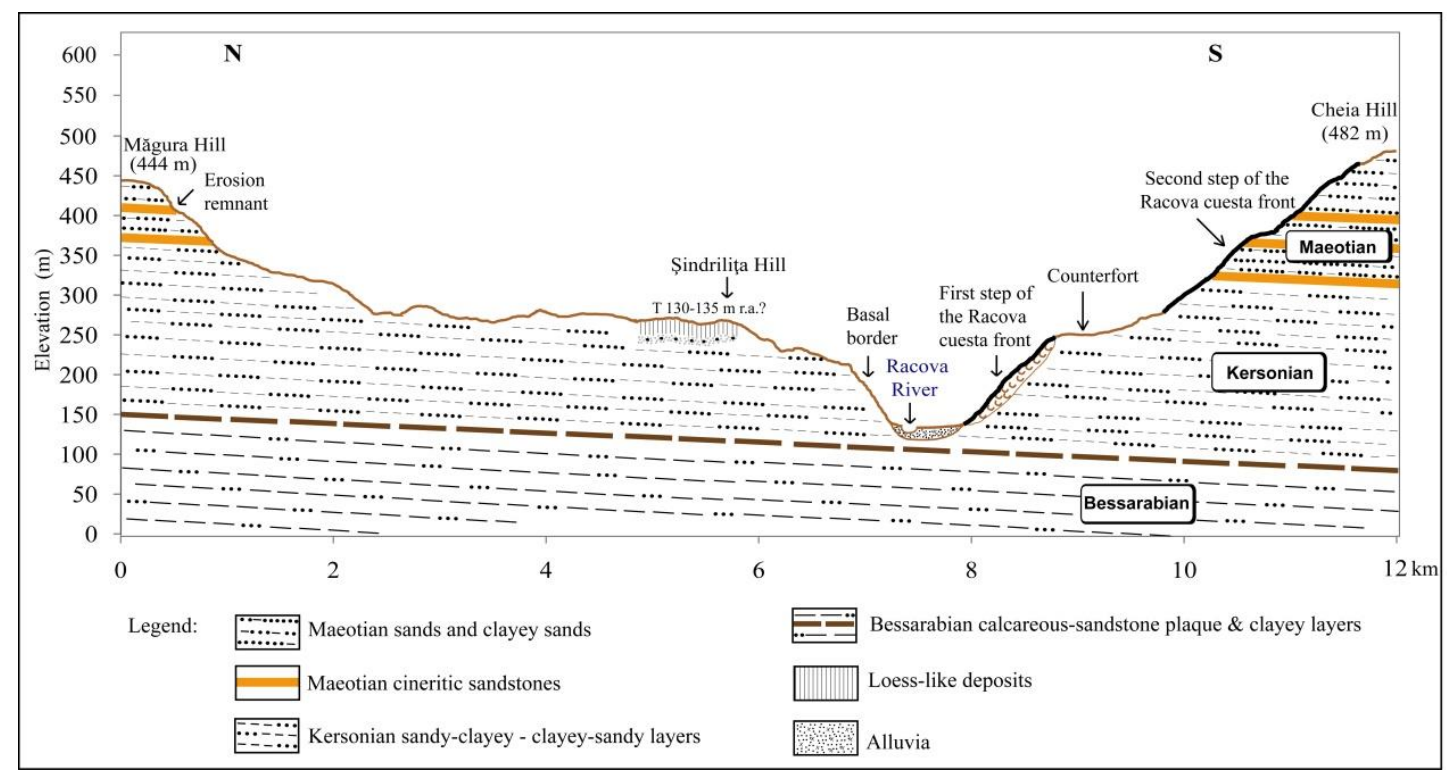

Fig. 11. Geomorphological cross section through the middle Racova Catchment between Măgura Hill and Cheia Hill

Compared to the initial situation, the left side is much narrower, as confirmed by the balance between the areas of the two parts of the Racova Catchment, the left side holds 53\% and the right side $47 \%$, respectively. This distribution radically differs from that in the western compartment. It is associated both with the blockade or delay exercised by the right tributaries from the Racova cuesta front upon the normal evolution of the base of the cuesta back slope, and to the southward homoclinal shifting of the Stemnic Valley to the prejudice of Racova back slope. The issue arising now relates to the beginning of the basal border shaping of the left side of Racova. According to Sârcu I. (1967) the $60 \mathrm{~m}$ r.a. fluvial terrace of Bârlad Valley at Crasna is Riss in age and by analogy we assign the same age to the basal border from the left side of Racova. Since that glacial period, with the glacial maximum placed 150,000 years 
ago, the homoclinal migration of the Racova back slope was greatly slowed down, which explains the low extension of the lower terraces. Moreover, due to fragmentation/dissection of land and gravel scarcity in the Central Moldavian Plateau, the upper terraces $\geq 60 \mathrm{~m}$ relative altitude were not preserved either on large surfaces in the Racova Catchment.

The eastern compartment covers the end of the lower catchment, occupying an area of $1,905.4$ ha (5.8\% of total area). The geological formations here belong only to the Kersonian, the Maeotian being eroded. The Racova valley has a typical subsequent character, with the cuesta front associated to its narrow right valley side, of smaller ampleness $(<160 \mathrm{~m})$, unitary and amounting $46 \%$ of the compartment area. The left valley side, southern looking cuesta back slope holds $54 \%$ of the total area and remains fairly even, slightly dissected by small re-consequent valleys (Târgului, Hopului, Hăşculeţ). This young compartment was formed by progressive evolution, respectively, by the slight increase in length of Racova in the area of the fluvial terraces from the right side of the Bârlad Valley, which slightly migrated eastwards.

\section{Conclusions}

Racova Catchment was carved above the Bessarabian calcareous-sandstone plaque in clay-sandy - sandy-clayey layers, Middle and Late Miocene in age. They belong mainly to the Kersonian (Upper Sarmatian) integrally developed on vertical and subordinate to the Maeotian, which imposes upon the relief by the cineritic sandstones of Nuţasca-Ruseni.

The almost equal value and distribution of geo-declivities on both sides of the Racova Catchment is determined mainly by the strong horizontal and vertical fragmentation/dissection of the relief, and by the geological and climatic conditions.

This is a typical hilly area, specific to the Central Moldavian Plateau, where the structural relief, in the form of structural-lithological plateaus, has a reduced and peripheral incidence. By this geomorphological particularity, the Racova Catchment differs net from the upper Bârlad Catchment, including that of Crasna, formed and developed in similar geological formations.

The sculptural (fluvio-denudational) relief in the general homoclinal structure amounts $83.1 \%$ of total area. Among its landforms, the predominance of the valley sides $(78.3 \%$ of catchment area) is noticeable, and slopes often play the role of front or cuesta back slope. The subsequent valley of Racova imposes in the relief the first-order structural asymmetry. The valleys of the re-consequent tributaries and some more evolved obsequent valleys emphasize the more blurred $2^{\text {nd }}$ order structural asymmetry. Hence, the marked extension of the cuestas is the basic feature of the local landforms. On the whole, the cuesta fronts amounts $62 \%$ of the slopes area, and two-thirds of the cuesta back slopes are heavily degraded.

Due to the severe dissection of the relief, lack of gravel, specific to the Central Moldavian Plateau and the high intensity of land degradation the fluvial terraces have a very narrow spread.

Based on field data, three distinct compartments have been separated. The western compartment includes the upper catchment, upstream of Bleşca, where the Racova Valley is diagonally (askew) subsequent, and most of the tributaries are re-consequent. It was formed by the recent, regressive evolution of the streams. The cuesta front of Racova is restricted but unitary, and the broadly extended cuesta back slope (77\% of total) is slightly incised by the left-handed re-consequent tributaries. 
The central compartment, the largest, more developed and most representative one is very dissected by the tributaries of Racova. The outcrop of the Maeotian cineretic sandstones contribute to shaping of the imposing upper step of the Racova double cuesta front. Here, the Racova Valley is typically subsequent, but its left side is far away different from the classical shape of a cuesta back slope and has a basal border of approximately $60-70 \mathrm{~m} \mathrm{r}$.a. There is a balance between the two sides of the catchment (53\% on the left and $47 \%$ on right) due to the southward homoclinal shifting of the Stemnic valley and the impact of the right tributaries from the Racova cuesta front on the normal evolution of the left side of Racova.

The eastern compartment, typically subsequent, is younger but progressively formed in the area of the fluvial terraces from the right side of the Bârlad Valley, which slightly migrated eastwards.

\section{References}

1. Andrei A., 2016. Studiul geomorfologic al degradărilor de teren din bazinul râului Şacovăț, Teză de doctorat, Univ. „Al. I. Cuza”, Iași.

2. Băcăuanu V., 1968. Câmpia Moldovei-studiu geomorfologic. Editura Ac. R.P. România, Bucureşti.

3. Băcăuanu V., Barbu N., Maria Pantazică, Ungureanu A., Chiriac D., 1980. Podişul Moldovei. Natură om, economie. Editura Ştiinţifică şi Enciclopedică, Bucureşti.

4. Bojoagă I., 2015. Bazinul râului Stemnic (Buda). Studiu pedo-geomorfologic, Teză de doctorat, Univ. „Al. I. Cuza”, Iași.

5. Budui V., 2009. Podişul Central Moldovenesc dintre Siret şi Şacovăț. Studiu fizico-geografic, Teză de doctorat, Univ. „Al. I. Cuza”, Iași.

6. Curea D., 2015. Relaţii pedo-geomorfologice în bazinul mijlociu al Prutului între Ţuţora şi Gorban (Faţa Prutului), Teză de doctorat, Univ. „Al. I. Cuza”, Iași.

7. Darie (căs. Chelaru) P., 2013. Studiul geomorfologic al degradărilor de teren din bazinul Crasnei. Teză de doctorat, Univ. „Al. I. Cuza”, Iași.

8. David M., 1921. O schiţă morfologică a Podişului sarmatic din Moldova. Bul. Soc. Rom. Geogr. Tom XXXIX (1920), Bucureşti.

9. David M., 1922. Cercetări geologice în Podişul Moldovenesc. Anuarul Institutului Geologic al României, IX (1915-1921), Bucureşti.

10. David M., 1941. Relieful Coastei Iaşilor şi problemele pe care le ridică sub raportul geomorfologic şi antropogeografic, Lucr. Soc. Geogr. „D. Cantemir”, tom III, Iași.

11. Donisă I., Boboc N., Ioniţă I., 2009. Dicţionar geomorfologic cu termeni corespondenţi în limbile engleză, franceză şi rusă, Editura Univ. „Al. I. Cuza”, Iași., 414 pp, ISBN 978-973-703-486-1.

12. Hârjoabă I.,1968. Relieful colinelor Tutovei, Editura Academică, Bucureşti.

13. Ionesi L., 1989. Geologia Românei: unități de platformă şi Orogenul Nord-Dobrogean, Editura Univ. „Al. I. Cuza”, Iași.

14. Ionesi L., 1994. Geologia unităţilor de platformă şi a Orogenului Nord-Dobrogean, Editura Tehnică, Bucureşti.

15. Ioniță I., 1985. Considerații privind simetria și asimetria unor văi din partea sudică a a Podișului Moldovei, Lucrările Seminarului Geografic D. Cantemir, numărul 3, pagina 71-78, Iași.

16. Ioniță I., 1998. Studiul geomorfologic al degradărilor de teren din bazinul mijlociu al Bârladului. Teză de doctorat, Univ. „Al. I. Cuza”, Iași.

17. Ioniță I., 2000. Relieful de cueste din Podișul Moldovei, Editura Corson, Iași.

18. Jeanrenaud P., 1966. Contribuții la cunoașterea geologiei regiunii dintre valea Siretului și valea Bârladului, Anal. Șt. Univ. „Al. I. Cuza”, Iași, tom XII.

19. Jeanrenaud P., 1971 a. Harta geologică a Moldovei centrale dintre Siret și Prut. Anal. Șt. Univ. ”Al. I. Cuza" Iași,, Iaşi, s. II, t. XVII. 
20. Jeanrenaud P., 1971 b. Geologia Moldovei centrale dintre Siret şi Prut, Rezumat teză de doctorat, Univ. „Al. I. Cuza”, Iași.

21. Jeanrenaud P., Saraiman A., 1995. Geologia Moldovei centrale dintre Siret și Prut, Editura Univ. „Al. I. Cuza", Iași.

22. Martiniuc C., 1955. Podişul Moldovenesc. „Geografia fizică a R.P. Române”, curs litogr., Bucureşti.

23. Patriche C., 2003. Podişul Central Moldovenesc dintre râurile Vaslui şi Stavnic. Studiu de geografie fizică,Teză de doctorat, Univ. „Al. I. Cuza”, Iași.

24. Ploscaru D., 1973. Podișul Central Moldovenesc. Studiu geomorfologic, Teză de doctorat, Univ. „Al. I. Cuza", Iași.

25. Puflea S., 2014. Bazinul Stavnicului. Studiu geomorfologic, Teză de doctorat, Univ. „Al. I. Cuza”, Iași.

26. Sîrcu I., 1956. Terasa de 65-70 m a Bârladului de la Crasna, Anal. Șt. Univ. „Al. I. Cuza”, Iași, tom XIII.

27. Topşa G., 2011. Bazinul mijlociu şi inferior al Vaslueţului. Studiu geomorfologic, Teză de doctorat, Univ. „Al. I. Cuza”, Iași.

28. Văscăuţeanu Th., 1928. Fauna argilelor sarmatice de la Ungheni, Anal. Inst. Geol. Rom., tom XIII.

29. *** LiDAR images 2012 delivered by Administraţia Bazinală de Apă Prut-Bârlad. 